\title{
Cutaneous manifestations in end-stage renal disease
}

\author{
Manifestações cutâneas na doença renal terminal
}

\author{
Omar Lupi ${ }^{1}$ \\ Marlene Sessim ${ }^{4}$ \\ Deilton Junior Duarte ${ }^{2}$ \\ Omar da Rosa Santos ${ }^{8}$
}

\author{
Ludimila Rezende ${ }^{2}$ \\ Cíntia Botelho Silveira ${ }^{5}$ \\ Priscilla Cardim 6
}

\author{
Mariane Zangrando ${ }^{3}$ \\ Maria Anísia Silva Sepulcri ${ }^{2}$ \\ Mário Meyer Fernandes ${ }^{7}$
}

\begin{abstract}
The prevalence of chronic kidney disease has increased over the last years. The effects of this disease are complex and may lead to dysfunction of multiple organs, including the skin, with most patients presenting with at least one dermatologic alteration. Sometimes these symptoms can be the first clear sign of kidney disease. This article discusses the skin manifestations related to severe renal impairment or end-stage renal disease (ESRD), which are divided into nonspecific and specific, and reviews the clinical features, etiopathogenesis and therapeutic options for these dermatoses. Early recognition and treatment reduce morbidity and improve these patients' quality of life.

Keywords: Calcinosis; nephrogenic fibrosing dermopathy; Chronic kidney failure; Skin manifestations; Pruritus

Resumo: A prevalência da doença renal crônica aumentou nos últimos anos. Os efeitos dessa doença são complexos e podem levar à disfunção de múltiplos órgãos, entre eles, a pele. A maioria dos pacientes apresenta pelo menos uma alteração dermatológica. Algumas vezes, esses sintomas podem ser o primeiro sinal evidente de doença renal. Este artigo aborda as manifestações cutâneas relacionadas a disfunção renal grave ou doença renal terminal, divididas em não específicas e específicas, revisando quadro clínico, etiopatogenia e opções terapêuticas dessas dermatoses. Seu reconhecimento e tratamento precoces diminuem a morbidade, melhorando a qualidade de vida desses doentes.

Palavras-chave: Calcinose; Dermopatia fibrosante nefrogênica; Falência renal crônica; Manifestações cutâneas; Prurido
\end{abstract}

\footnotetext{
Received on 19.02 .2010

Approved by the Advisory Board and accepted for publication on 20.08.2010

* Work conducted at the Dermatology Service of the General Polyclinic of Rio de Janeiro and at the Internal Medicine Service (10th Ward) - School of Medicine and Surgery, Federal University of Rio de Janeiro State (UNIRIO) - Rio de Janeiro (RJ), Brazil.

Conflict of interest: None / Conflito de interesse: Nenbum

Financial funding: None / Suporte financeiro: Nenbum

Professor (PhD) of Dermatology, Department of Medical Specialties - School of Medicine and Surgery, Federal University of Rio de Janeiro State (UniRio) Professor and Head of the Dermatology Service, General Polyclinic of Rio de Janeiro (PGRJ) - Rio de Janeiro (RJ), Brazil.

Intern, Postgraduation Course in Dermatology, General Polyclinic of Rio de Janeiro (PGRJ) - Rio de Janeiro (RJ), Brazil.

Postgraduate Student of Dermatology, Central Army Hospital (Hospital Central do Exercito -HCE) - Rio de Janeiro (RJ), Brazil

Postgraduate Student of Dermatology, General Polyclinic of Rio de Janeiro (PGRJ) - Rio de Janeiro (RJ), Brazil.

Resident in Dermatology, ABC Medical School - Sao Paulo (SP), Brazil.

Tenth-term PhD Student, School of Medicine and Surgery, Federal University of Rio de Janeiro State (UNIRIO) - Rio de Janeiro (RJ), Brazil.

Professor (PhD) of Internal Medicine - Department of Internal Medicine - School of Medicine and Surgery, Federal University of Rio de Janeiro State (UNIRIO)

Full Professor of Internal Medicine - Department of Internal Medicine - School of Medicine and Surgery, Federal University of Rio de Janeiro State (UNIRIO) Rio de Janeiro (RJ), Brazil.
}

CC2011 by Anais Brasileiros de Dermatologia 


\section{INTRODUCTION}

Chronic kidney disease is currently an important public health issue. ${ }^{1.2}$ In Brazil, the prevalence of patients on a chronic dialysis program increased about $40 \%$ from January 2004 to March $2008^{3}$.

Some mechanisms for the progression of renal dysfunction include hyperlipidemia, hyperglycemia and hypertension. ${ }^{4}$ In this context, hypertensive and diabetic nephropathy are currently the main causes of end-stage renal disease (ESRD). ${ }^{1-3}$ In the long run, such entities cause a change in the renal microvasculature, leading to the passage of proteins. A permanent lesion on the blood vessels causes sclerosis, overloading the nephrons, which lose their ability to adapt and, consequently, their function. ${ }^{4.5}$

In end-stage renal failure, with the progressive decline of glomerular filtration rate, the kidney fails to maintain normal levels of waste products of protein metabolism such as urea and creatinine. In addition to these, sodium, calcium and phosphate are the major agents involved in the pathogenesis of skin changes of severe kidney disease. ${ }^{4.5}$

The effects of ESRD are complex and can lead to dysfunction of multiple organs, including the skin. Early diagnosis and treatment in patients with renal disease enable a better quality of life, delaying the onset of skin manifestations. However, these manifestations can be observed from the onset of the disease to progression to the terminal stage, in uremia, and after renal transplantation. ${ }^{6.7}$

The major skin manifestations in ESRD are xerosis, pruritus, hyperpigmentation, perforating and calcifying disorders and bullous diseases. ${ }^{6-11}$ About 50$100 \%$ of the patients present with at least one skin lesion. ${ }^{7}$ Sometimes these symptoms can be the first clear sign of kidney disease. ${ }^{10}$

This review focuses on the skin manifestations of severe renal impairment or ESRD. Such manifestations of ESRD can be divided into nonspecific and specific. In the first group we can highlight changes in skin color, elastosis, ecchymoses, xerosis, pruritus, uremic frost, half and half nails and gynecomastia. The second group comprises perforating disorders, metastatic calcification, uremic fibrotic dermopathy and bullous diseases ${ }^{7}$.

\section{NON-SPECIFIC MANIFESTATIONS}

Changes related to color include pallor, attributed to the anemia of chronic disease and erythropoietin deficiency, yellowing of the skin due to retention of fat-soluble pigments in the dermis and subcutaneous tissue, such as carotenoids and urobilinogen; grayish-brown skin, due to the deposit of hemosiderin; hyperpigmentation associated with sun exposure, as well as elastosis; hyperchromia (Figure 1) after initiation of dialysis. Ecchymosis (Figure 2) is common, secondary to platelet dysfunction. ${ }^{6.7}$ It is known that high concentrations of urea can induce change in platelet aggregation; however, in ESRD, there is also an important participation of guanidinosuccinic acid buildup, which can reach levels thirty times higher than normal. This acid inhibits ADP-induced platelet activity being, therefore, one of the factors involved in uremic bleeding. ${ }^{5.12}$

Xerosis (Figure 3) is a complication frequently observed in ESRD patients in 50-85\% of the cases, mainly in patients who have not started dialysis. ${ }^{7}$ It is known that in most cases it disappears after renal transplantation. It is classicaly absent in acute renal failure and is not correlated with the level of plasma urea. Uremic xerosis is suggested as the main factor in the onset of pruritus. It is believed that xerosis should be considered a syndrome, according to topography and presence of clinical signs, such as itching and skin turgor. The pathophysiological mechanism of xerosis is unknown, but there is probably a relationship between the dysfunction of eccrine glands and depletion of volume attributed to the use of diuretics. ${ }^{13}$

The dry skin of uremic xerosis is often associated with signs of skin turgor and elastosis, indicating significant changes in the structure of the skin underlying the epidermis (increased extensibility of the skin, elastin fragmentation, atrophy of sebaceous and sudoriferous glands) that can translate into dehydration due to thickening of the skin. It can be correlated with decreased sweating, atrophy of the sebaceous glands and the secretory and ductal portion of sudoriferous glands, lowering the level of

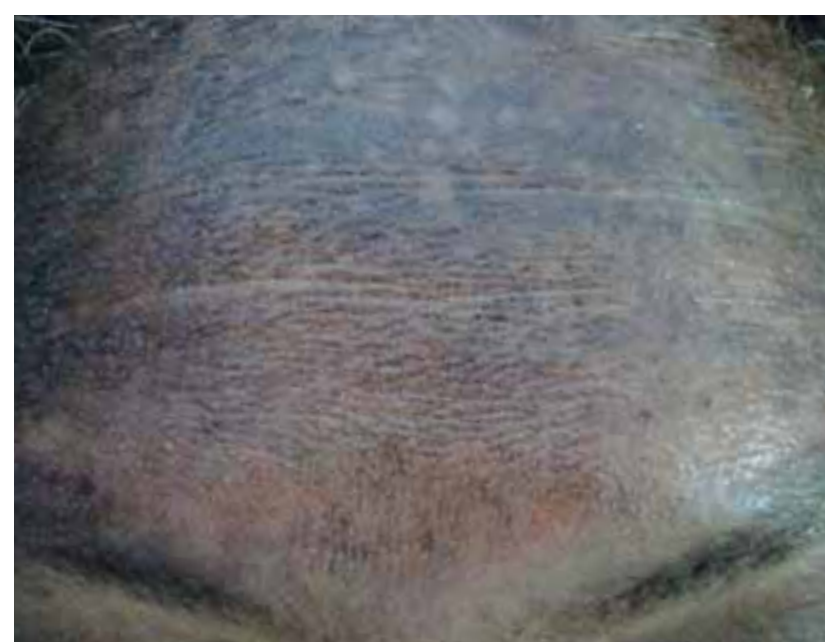

FIGURE 1: Hyperchromic macules with a reticulated aspect in the frontal region of a patient with chronic renal failure undergoing hemodialysis 


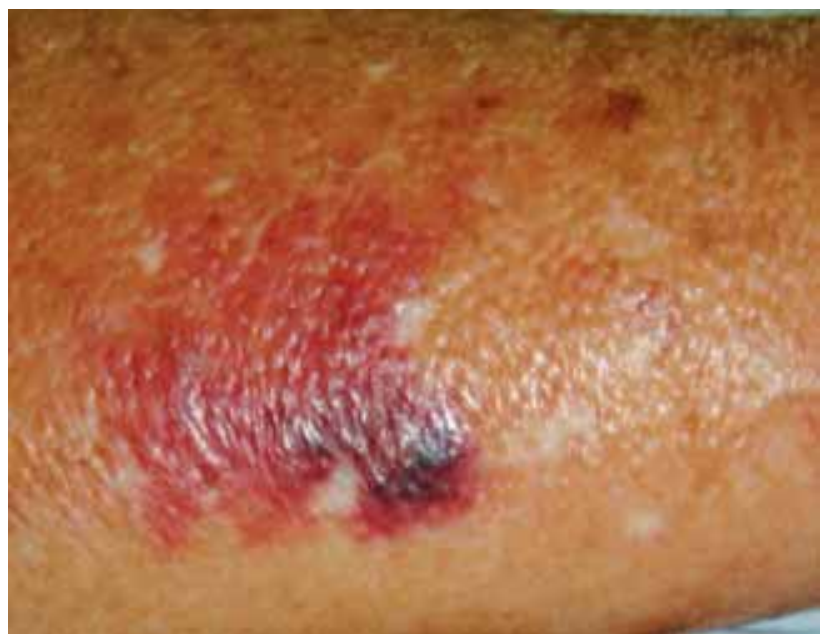

Figure 2: Spontaneous ecchymotic injury on the upper limb of a patient with chronic renal failure

lipids in the skin surface and losing the integrity of the stratum corneum by reducing its water content. A decrease in the number of sudoriferous glands can also be noticed. Xerotic skin, in severe cases, acquires an ichthyosiform aspect. These changes are responsible for premature skin aging in chronic renal patients. Moisturizers associated with 5-10\% urea cream or $2-3 \%$ salicylic acid can be used in the treatment. ${ }^{13-15}$

Pruritus may be localized or disseminated and is the most common symptom of ESRD. It occurs in about 53\% of these patients, causing great harm to their quality of life. ${ }^{6,15,16}$ It is not associated with other primary or systemic skin diseases, psychological disorders or acute renal failure. The pathogenesis is not fully known, but there is a relation with hyperparathyroidism, xerosis, hypervitaminosis A, iron deficiency anemia, and elevated serum levels of magnesium, calcium, phosphate, aluminum and histamine, though the latter may be associated with allergic sensitization to components in dialysis membranes. Pruritus 9.17 to 20 contributes to the appearance of perforating injuries by the Koebner phenomenon. ${ }^{6}$

The treatment of pruritus has shown variable efficacy and is a challenge. Topical and oral medication are therapeutical options. The use of antihistamines is not always effective. Other options of oral medication are serotonin antagonists, ondansetron, activated charcoal and cholestyramine. Opioid antagonist has shown benefits in the short term, having the advantage of presenting few side effects. High-potency topical corticosteroids, or under occlusion, and infiltration of corticoid were beneficial for some patients; however, they do not prevent the development of new lesions. Topical and oral

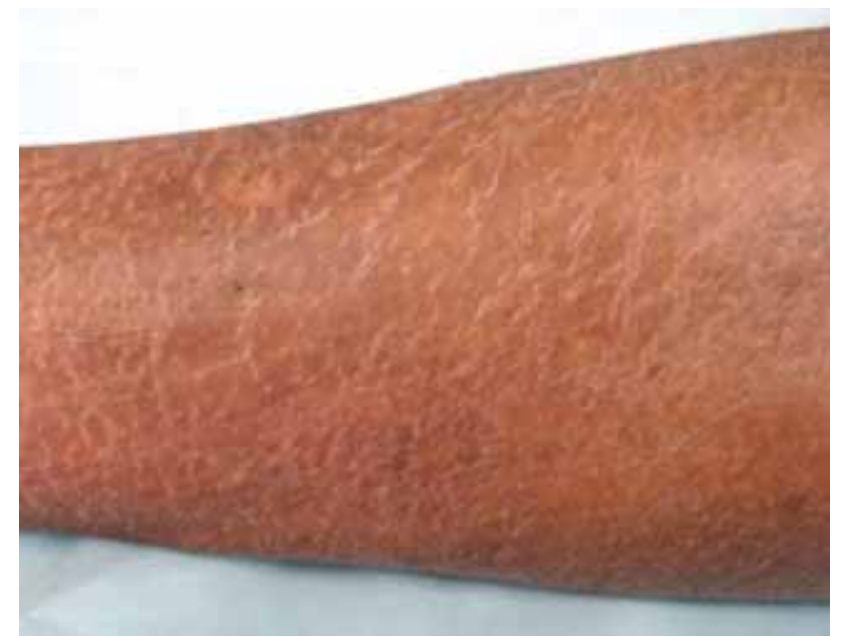

FIGURE 3: Skin xerosis evolving with ichthyosiform appearance in the lower limb of a chronic renal patient

retinoids and vitamin $\mathrm{A}$ have had positive results. Topical capsaicin, 025\%, may be used with good results. Cryotherapy and keratolytic drugs have been effective in some cases. Phototherapy with UVA and UVB (narrow-band) is a good option, but in recommending this procedure, immunosuppression in kidney-transplanted patients and the potential risk of carcinogenesis should be considered. ${ }^{19,21-25}$

One of the rarest presentations is uremic frost, which occurs in only 3\% of the patients with ESRD. ${ }^{9}$ It is related to frank uremia and may be recognized as a white deposit on the skin, secondary to crystallized urea excreted in sweat. This manifestation responds well to dialysis. ${ }^{6.8,9}$

The nails may show a number of changes. The most typical alteration of ESRD is called half-and-half nail and is frequently found in $21 \%$ of the patients. It is characterized by a marked brownish or pinkish discoloration in the nail extremity (Figure 4). Such manifestation is more prevalent in dialysis patients. There may be remission after renal transplantation. The pathogenesis is attributed to an increase of the melanocyte stimulating hormone (MSH). ${ }^{7-9}$

Gynecomastia may be observed in patients with chronic renal failure, which is attributed to the accumulation of prolactin. Its high serum levels (above 30ug / L) are directly related to worsening of the renal function. In such cases, hyperprolactinemia inhibits the release of the follicle stimulating hormone (FSH) and luteinizing hormone, resulting in lower production of estrogen and progesterone. The dermatologic implications are gynecomastia in men and hirsutism and acne in women. Acanthosis nigricans may develop due to insulin resistance promoted by excess prolactin. ${ }^{26}$

Regarding the main substances involved in the 


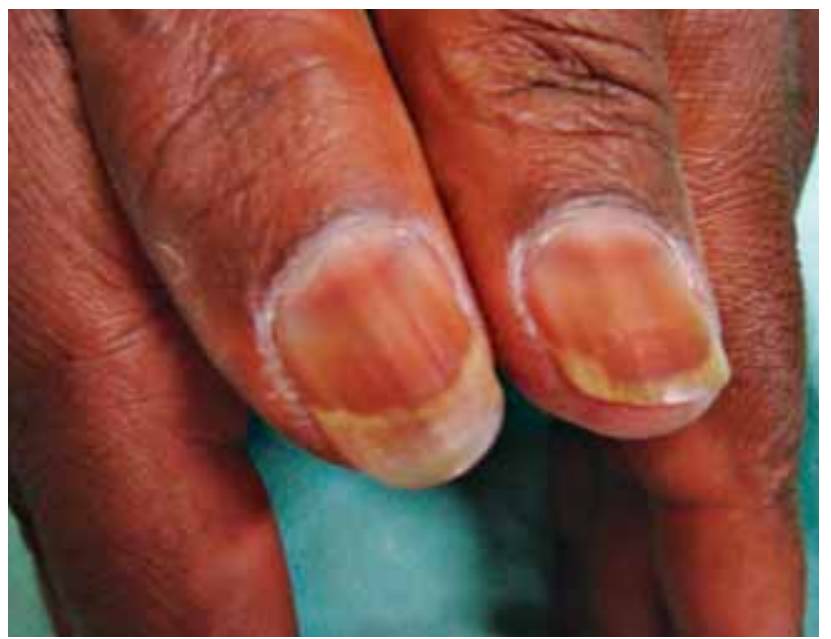

FIGURE 4: Light-colored proximal region and brownish distal region of the nail, characterizing half and half nail

dialysis treatment of ESRD, we can cite erythropoietin (EPO), calcitriol and calcium salts used as phosphate binders (calcium carbonate and acetate) which, although uncommon, may cause drug eruptions. With regard to EPO, the allergenic component is associated with the vehicle, not with the substance per se. Azevedo et al. observed intense pruritus without visible skin lesions when the lyophilized form of EPO was used, as compared with the solubilized form. ${ }^{27}$

Side effects of calcitriol are related to prolonged use of the drug without adequate supervision, leading to hypercalcemia and, subsequently, cutaneous calcification. Phosphate binders can also cause hypercalcemia; the lowest levels are of calcium oxalate due to the percentage of calcium in its composition. ${ }^{28}$

Chronic renal patients with ESRD are dependent on the conditions of a good arteriovenous fistula for a better quality of life. Hence, we must consider several factors such as good anamnesis and patient history and an appropriate physical examination with evaluation of the veins, arteries and the cardiopulmonary system, which can ensure the success of a good fistula, thus mimicking future complications.

The dermatologic complications most commonly associated with the manufacturing of the fistulas are necrosis caused by excessive manipulation of the skin, bruising, tightness in the skin suture and infectious processes. Treatment should be carried out with antibiotics and wound debridement. When infections are present, the association with synthetic arteriovenous graft is more common in $10 \%$ of the cases. ${ }^{29}$ Staphylococcus aureus is the bacterium most implicated in up to $80 \%$ of the cases and, less commonly, Staphylococcus epidermidis. Gram negative bacteria accounted for $15 \%$ of the infections. Treatment will differ according to the type of fistula, whether native or graft. With regard to native fistulas, the infection is usually associated with puncture failure or lack of patient's hygiene in the care of the fistula. The use of antibiotics for four to six weeks and wound care are sufficient, leaving surgery for cases of septic emboli. When in the presence of graft, resection of the infected area, together with the use of antibiotics, is necessary. The use of systemic antibiotics should follow the results of cultures (blood culture or culture of local secretion) that should have coverage for gram positive and negative bacteria until the isolation of the bacteria. Cephalosporins are the most commonly used antibiotics in monotherapy. In cases with complications, the association of vancomycin and aminoglycoside is recommended. ${ }^{30}$

\section{SPECIFIC MANIFESTATIONS}

The perforating disorders observed in ESRD patients share similar characteristics with primary perforating dermatoses, such as Kyrle's disease, perforating folliculitis and reactive perforating collagenosis. ${ }^{31.32}$

Kyrle's disease is traditionally described in young and middle-aged patients; it is present in $21 \%$ of the patients, in African Americans, and is associated with diabetes mellitus. ${ }^{7}$ The most common location is in the extremities and buttocks. Clinical examination reveals papules two to eight millimeters in diameter, with keratotic plug, some coalescing into plaques. The lesions may be follicular or extrafollicular; linear arrangement is common. Histology reveals parakeratotic plug with basophilic material and epidermal depression with or without follicular involvement. It usually presents with acanthosis around the epidermis, dyskeratosis and vacuolated epidermal cells, adjacent to the parakeratotic column. Follicular dilation of the infundibulum by parakeratosis, orthokeratosis and basophilic degeneration also occurs. ${ }^{6.7,931,32}$

Classical reactive perforating collagenosis is a genodermatosis of autosomal dominant or recessive inheritance, present in childhood and caused by trauma, folliculitis and exposure to cold weather. The acquired form in adults is associated with chronic kidney disease and may be a variant of perforating disorders. Clinically, this collagenosis starts with a brownish or pinkish papule that varies according to the patient's skin phototype. They may present as keratotic, umbilicated lesions, nodules and occasionally verrucous plaques with marked pruritus. They are distributed in exposed areas: face, upper and lower limbs, with minor involvement of the trunk. 
Lesions may have spontaneous regression, leaving a scar insofar as new lesions arise. The Koebner phenomenon is present. The classic pathology consists in cup-shaped extensive invaginations in epidermal surface, with basophilic degeneration forming collagen bands. Often, the disease can manifest before dialysis and in some transplanted patients. ${ }^{6.7,9,31.32}$

Histopathologically, perforating dermatoses are indistinguishable. Dilated hair follicles with keratotic plugs containing areas of parakeratosis, orthokeratosis, suppurative inflammation and basophilic necrotic material may be observed in new lesions. In old lesions elements of connective tissue and inflammatory cell degeneration are found, including foreign body giant cells. Degenerated elastic fibers are observed with specific stain (Verhoeff van Gieson) and those of collagen, with hematoxylineosin (HE). The pathogenesis of perforating dermatoses can be attributed to abnormal epidermal proliferation or collagen alteration. ${ }^{6.7,9,14,31,32}$

Perforating disorders occasionally have spontaneous regression; however, oral and topical retinoids and oral vitamin $A$ have been used in therapeutic management with positive results. Highpotency topical corticoids, or under occlusion, and infiltration of corticoids can also be used. Cryotherapy and keratolytic drugs have been successful in some cases. ${ }^{6.7,31.32}$

The differential diagnosis of perforating disorders can be done with the following diseases: verruca vulgaris, eruptive keratoacanthoma, nodular prurigo, hypertrophic lichen planus, follicular keratosis and phrynoderma ${ }^{6}$.

Among the calcifying disorders of the skin in chronic renal patients, metastatic calcification, cutaneous calcinosis and calciphylaxis have been reported. The first occurs by the precipitation of high levels of serum calcium and phosphorus. Chronic kidney disease is the major metabolic condition associated. Calcification can affect the gastric mucosa, vascular walls, lung, kidneys and subcutaneous tissue. ${ }^{6.8}$

Cutaneous calcinosis or benign nodular calcification consists in the deposition of insoluble calcium salts in the skin and subcutaneous tissue. It is characterized by stony papules, nodules and plaques of varied size, and there may be elimination of material through the epidermis. The sites most commonly affected are the periarticular regions and fingertips, the latter being extremely painful. The degree of involvement is correlated with high blood levels of calcium and phosphate, whose normalization can lead to the regression of lesions. Histopathology reveals homogeneous blue material in the superficial dermis, seen in HE staining, as well as globular deposits in the subcutaneous tissue. ${ }^{6.8}$ They are also observable in radiography.

Calciphylaxis, also known as necrotizing cutaneous calcification syndrome and, more recently, calcific uremic arteriopathy is a rare but significant cause of morbidity and mortality in patients with chronic kidney disease. The incidence is $4 \%$ in dialysis patients and $1 \%$ in patients undergoing conservative treatment. ${ }^{7.33}$ It is the consequence of calcification in arteries of small and medium caliber of the dermis and subcutaneous tissue, gradually progressing to skin necrosis (Figures $5 \mathrm{~A}$ and $\mathrm{B}$ ). It presents high mortality. It is most commonly seen in patients with severe renal failure as well as in patients with secondary or tertiary hyperparathyroidism and those
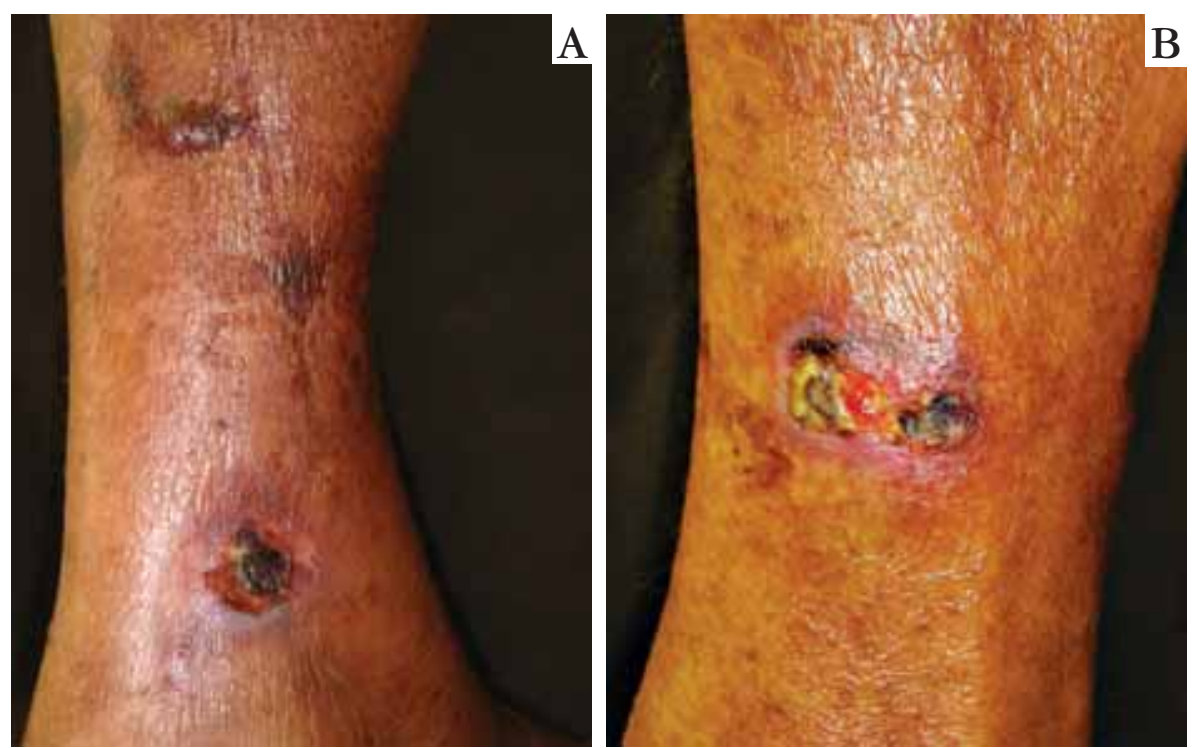

Figure 5A

e 5B:

Exulcerated

plaques

exposing sub-

cutaneous cal-

cium deposit

in the distal

region of the

lower limbs of

a chronic

renal patient 
transplanted; it may occur in other diseases. It is more common in females in a ratio of 3 to $1 .{ }^{33.34}$

Clinical symptoms consist of firm purpuric plaques or nodules, symmetrical, bilateral, with a reticulated pattern, resembling livedo reticularis. The localization of lesions can predict the prognosis. Lesions in the extremities of hands and feet, the penis, forearms and calves have a better prognosis when compared to lesions on the thighs, buttocks and trunk. Distal peripheral pulses are preserved in areas of necrosis. Myopathy, hypotension, dementia, fever, central nervous system infarction, or bowel or myocardium infarction have been reported in association with skin necrosis, the so-called systemic calciphylaxis. ${ }^{33.34}$

The histopathology of calciphylaxis is typical, but not pathognomonic. There is a typical calcification in arteries of small and medium caliber of the dermis and subcutaneous tissue, with intimal hyperplasia. Fibrin thrombi may be noted in the superficial dermis and subcutaneous tissue, as well as in the calcification of vessels in areas of epidermal necrosis. Calcium deposition around the adipocytes or global calcification of the septal capillaries may be seen in the subcutaneous tissue. ${ }^{7,33,34}$

Calcification is seen on radiographs as a dual in-line network. Vascular calcification is present in $10 \%$ of the patients who are undergoing hemodialysis, $58 \%$ of the patients with secondary hyperparathyroidism and 75\%, with tertiary hyperparathyroidism. The most sensitive radiological exam to detect calcification is mammography, but it is not routinely performed. ${ }^{6}$

The pathogenesis of calciphylaxis is multifactorial. Calcium, phosphate and parathyroid metabolism disorders are observed in the mechanism. Risk factors for the development of calciphylaxis include: high parathyroid hormone, calciumphosphate product greater than $50 \mathrm{mg}^{2} / \mathrm{dL}^{2}$, exposure to vitamin $\mathrm{D}$, idiopathic chronic kidney disease, immunosuppression, lymphoma, blood transfusion, intravenous calcitriol use, HIV and local trauma. ${ }^{6,33,34}$

Systemic vasculitis, CREST syndrome (calcinosis, Raynaud's phenomenon, esophageal changes, sclerodactyly and telangiectasia) and systemic lupus erythematosus are part of the differential diagnosis of calciphylaxis. ${ }^{7}$

In the management of calcinosis and calciphylaxis, longer survival in patients undergoing total or subtotal parathyroidectomy has been reported, as compared to those who are not submitted to this procedure. Rapid resolution of skin manifestations has been noted after surgery; however, regression of arterial calcification has not been shown. Surgical procedure has not been beneficial for patients with low levels of PTH. ${ }^{633,35}$

Treatment of calciphylaxis includes debridement, systemic antibiotics, biological or hydrocoloid dressings and skin grafting. Hyperbaric oxygen therapy has been beneficial in patients undergoing hemodialysis and in patients who showed no response to parathyroidectomy and debridement. This is explained by improvement of angiogenesis and phagocytosis, with inhibition of bacterial growth and reduction of local tissue edema. The effects of longterm oxygen therapy should be evaluated in larger studies. ${ }^{6.35}$

Within the group of bullous diseases observed in advanced kidney disease, we highlight porphyria cutanea tarda (PCT), also known as chronic hepatic porphyria, and pseudoporphyria (Table 1). Together, they have an incidence of $1.2 \%$ to $9 \% .{ }^{6}$ PCT is the result of congenital or acquired deficiency of the enzyme uroporphyrinogen III decarboxylase. It is classified as sporadic PCT or type I, and type II or hereditary PCT. In the sporadic form, the enzyme is deficient only in the liver; in the inherited form, the enzyme is deficient in all tissues, including red blood cells and fibroblasts. ${ }^{14,36,37,38,39}$ The prevalence of the disease is around $5 \%$ in 15 patients with chronic renal failure who maintain regular dialysis treatment. Other triggering factors of PCT include alcoholism, drugs (estrogens, hexachlorobenzene), iron, viral infections (hepatitis B, hepatitis C and HIV). ${ }^{6,7,36-38}$

The clinical presentation of PCT associated with ESRD does not differ from sporadic PCT. Features include tense vesicles and bullae distributed on the dorsum of the hands, face and occasionally the feet, followed by erosions and crusts. The lesions develop with scarring and milia. Skin fragility to minor trauma, post sun exposure hyperpigmentation with purple suffusion in the central part of the face, as well as sclerodermatous plaques and hypertrichosis are observed. Patients with all forms of PCT have increased serum iron and its liver reserves. Anuric patients and those with ESRD show high levels of uroporphyrin in the plasma, since there is no urinary excretion and hemodialysis is not effective to remove such substances. ${ }^{6,7,36-38}$ (Figure 5).

Histopathology is characterized by subepidermal blistering with little or no inflammatory infiltrate. The base of the bulla is irregular, with a festooning aspect even in the absence of epidermis. The basement membrane zone is evidenced with periodic acid-Schiff (PAS) staining. Direct immunofluorescence reveals deposits of IgG and C3 with a granular pattern in the dermoepidermal junction and in the vessel walls. ${ }^{7,36-40}$

It may be differentiated from pseudoporphyria, 
ChART 1: Differentiation of porphyria cutanea tarda and pseudoporphyria

\begin{tabular}{|c|c|c|}
\hline MANIFESTATIONS & PORPHYRIA CUTANEA TARDA & PSEUDOPORPHYRIA \\
\hline $\begin{array}{l}\text { CLINICAL } \\
\text { MANIFESTATIONS }\end{array}$ & $\begin{array}{l}\text { Bullae on the dorsum of hands and feet, in } \\
\text { the face (periorbital hyperpigmentation), } \\
\text { sclerodermatous plaques, hypertrichosis. }\end{array}$ & $\begin{array}{l}\text { Absence of sclerodermatous plaques and } \\
\text { hypertrichosis. Related to drug use. }\end{array}$ \\
\hline HISTOPATHOLOGY & $\begin{array}{l}\text { Subepidermal blistering with little or } \\
\text { no inflammatory infiltrate. The base of } \\
\text { the bulla is irregular with a festooning } \\
\text { aspect even in the absence of epidermis. }\end{array}$ & Identical to that of PCT. \\
\hline LABORATORY & Serum uroporphyrinogen III increase & Normal serum uroporphyrinogen III values \\
\hline TREATMENT & $\begin{array}{l}\text { Photoprotection }+ \text { dialysis } \\
\text { (resolution in } 37 \% \text { of the cases) }\end{array}$ & Drug withdrawal (spontaneous regression). \\
\hline
\end{tabular}

epidermolysis bullosa acquisita and bullous pemphigoid. ${ }^{6}$

Pseudoporphyria is a condition similar to PCT, but with no clear porphyrin abnormalities. This disorder may be associated with drugs such as furosemide, nalidixic acid, tetracycline, naproxen, cyclooxygenase inhibitors, and amiodarone, or with the excessive use of UVA tanning beds. Clinical features and histopathology are similar to those of PCT; hypertrichosis and sclerodermatous plaques are rare. Histopathology evidentiated cell-poor subepidermal blistering and a thin, blood-poor vascular wall, visualized by PAS. ${ }^{36,40,41}$ (Table 1 ).

This disease may have differential diagnosis with cutaneous porphyria tarda and drug reactions. ${ }^{6}$

For the treatment of PCT and pseudoporphyria, a broad-spectrum sunscreen against UVA rays should be recommended and the use of alcohol and estrogens, avoided. Unfortunately, uroporphyrin cannot be removed efficiently during dialysis. Dialysis, when performed using a high-flow dialyzer with polysulfate, can reduce up to $37 \%$ the level of plasma porphyrin, but it does not lead to clinical remission. Phlebotomies performed in small volumes (50-100 $\mathrm{ml}$ ) every week for over a year are thoguht to induce remission. The use of phlebotomy in conjunction with the administration of erythropoietin mobilizes hepatic iron stores. Iron chelators such as deferoxamine have shown therapeutic success, but they cannot be used continuously due to side effects. Chloroquine increases the solubility of porphyrin and facilitates urinary excretion, but is not effective in anuric patients. Plasmapheresis has limited use in the removal of porphyrin due to its high cost. ${ }^{6,36,41}$

Fibrotic uremic dermopathy (FUD), now mostly known as nephrogenic systemic fibrosis (NSF), is associated with increased tissue deposition of collagen, causing thickening and hardening of the skin and fibrosis that can affect other organs. It is clinically characterized by a diffusely thin, hyperpigmented skin with occasional discreet papules and nodules. Eruptions begin in the extremities, ascending to the trunk, but rarely involving the face. Yellowish papules can be observed in the palmar region and yellow nodules, in the sclera. Itching, burning sensation and pain were also described. ${ }^{7,40,42-44}$

Recently, NSF has been described in patients with end-stage renal failure with metabolic acidosis who underwent magnetic resonance angiography, probably with an injection of a large amount of gadolinium-based paramagnetic contrast agents. This substance is toxic, so there is greater concern in patients with renal failure due to decreased clearance. Skin manifestations occur sixteen days after the injection of contrast and this prolonged duration may explain why this relationship has not been previously described. The safety of administration of these contrast agents in patients with renal failure is not well established. ${ }^{45.46}$

\section{CONCLUSION}

Skin manifestations are fairly common in patients with chronic kidney disease. They negatively affect these patients' quality of life, being a reason of constant worry on the part of the health care team. Fortunately, with the advent of increasingly effective renal replacement therapies, some skin changes, previously seen with frequency in ESRD patients - for instance, uremic frost syndrome - have become increasingly rare. But others, such as uremic pruritus and calciphylaxis, which do not respond to dialysis, 
often constitute therapeutic challenges. Therefore, it is necessary that health professionals who deal with these patients on a daily basis have knowledge about these events. In this way, they will be able to establish early diagnosis and proper treatment and collaborate on research in order to elucidate their pathophysiology and seek new therapies for these diseases.

\section{REFERENCES}

1. United States Renal Data System 2009 annual data report volume two: atlas of end stage renal disease in the United States. [Acesso 22 nov. 2009]. Disponível em: http://www.usrds.org.

2. Romão Junior JE. Doença renal crônica: definição, epidemiologia e classificação. J Bras Nefrol. 2004;26:1-3.

3. Sociedade Brasileira de Nefrologia. Censo de diálise 2008. [Acesso 23 nov. 2009]. Disponivel em: http://www.sbn.org.br

4. Luke RG. Insuficiência renal crônica. In: Goldman L, Bennet JC editors. Cecil: tratado de medicina interna. 21 $1^{\circ}$ ed. Rio de Janeiro: Guanabara Koogan; 2001. p. $632-44$

5. Nucete MR. Conceptos actuales sobre la fisiopatología clínica y alteraciones bioquímicas del síndrome urémico: una revisión. Medula. 1998;7:35-41.

6. Robinson-Bostom L, DiGiovanna JJ. Cutaneous manifestations of end-stage renal disease. J Am Acad Dermatol. 2000;43:975-86.

7. Abdelbaqi-Salhab M, Shalhub S, Morgan MB. A current review of the cutaneous manifestations of renal disease. J Cutan Pathol. 2003;30:527-38.

8. Avermaete A, Altmeyer P, Bacharach-Buhles M. Skin changes in dialysis patients: a review. Nephrol Dial Transplant. 2001:16:2293-6.

9. Udayakumar P, Balasubramanian S, Ramalingam KS, Lakshmi C, Srinivas CR, Mathew AC. Cutaneous manifestations in patients with chronic renal failure on hemodialysis. Indian J Dermatol Venereol Leprol. 2006;72:119-25.

10. Hajheydari Z, Makhlough A. Cutaneous and mucosal manifestations in patients on maintenance hemodialysis: A Study of 101 Patients in Sari, Iran. A Study of 101 Patients in Sari, Iran. Iran J Kidney Dis. 2008;2:86-90.

11. Cordova KB, Oberg TJ, Malik M, Robinson-Bostom L. Dermatologic conditions seen in end-stage renal disease. Semin Dial. 2009;22:45-55.

12. Cases A, Escolar G. Diátesis hemorrágica en la uremia. Nefrologia. 1998:18:270-82.

13. Szepietowski JC, Reich A, Schwartz RA. Uraemic xerosis. Nephrol Dial Transplant. 2004;19:2709-12.

14. Azulay RD, Azulay DR, Azulay-Abulafia L. Dermatologia. 5 ed. Rio de Janeiro: Guanabara Koogan; 2008. p.232-233;532;633.

15. Kuypers DR. Skin problems in chronic kidney disease. Nat Clin Pract Nephrol. 2009;5:157-70.

16. Pisoni RL, Wilkström B, Elder SJ, Akizawa T, Asano Y, Keen ML, et al. Pruritus in haemodialysis patients: International results from the Dialysis Outcome and Practice Patterns Study (DOPPS). Nephrol Dial Transplant. 2006;21:3495-505.

17. Welter EQ, Bonfá R, Petry V, Moreira LL, Weber MB. Relação entre grau de prurido e qualidade de vida de pacientes em hemodiálise. An Bras Dermatol. 2008;83:137-40.

18. Ikoma A, Rukwied R, Stander S, Steinhoff M, Miyachi Y, Schmelz M. Neurophysiology of Pruritus: interaction of itch and pain. Arch Dermatol. 2003;139:1475-8.

19. Mettang T, Pauli-Magnus C. The pathophysiological puzzle of uremic pruritus: insights and speculations from therapeutic and epidemiological studies. Perit Dial Int. 2000;20:493-4

20. Murphy M, Carmichael AJ. Renal itch. Clin Exp Dermatol. 2000;25:103-6.

21. Jamal A, Subramanian PT. Pruritus among end-stage renal failure patients on hemodialysis. Saudi J Kidney Dis Transpl. 2000;11:181-5.

22. Yosipovitch G, Duque MI, Patel TS, Ishiuji Y, Guzman-Sanchez DA, Dawn AG, et al. Skin barrier structure and function and their relationship to pruritus in end-stage renal disease. Nephrol Dial Transplant. 2007;22:3268-72.

23. Morton CA, Lafferty M, Hau C, Henderson I, Jones M, Lowe JG. Pruritus and skin hydration during dialysis. Nephrol Dial Transplant. 1996;11:2031-6.

24. Gunal Al, Ozalp G, Yoldas TK, Gunal SY, Kirciman E, Celiker H. Gabapentin therapy for pruritus in haemodialysis patients: randomized, placebo-controlled, double-blind trial. Nephrol Dial Transplant. 2004;19:3137-9.

25. Wikström B, Gellert R, Ladefoged SD, Danda Y, Akai M, Ide K, et al. Kappa-opioid system in uremic pruritus: multicenter, randomized, double-blind, placebocontrolled clinical studies. J Am Soc Nephrol. 2005;16:3742-7.

26. Löcsey L, Lenkey À, Leövey A. Hormonal changes in haemodialysed and in kidney- transplantes patients. Int Urol Nephrol. 1987;19:201-213.

27. Azevedo LS, Fonseca JA, Godoy $\mathrm{AD}$, Atallah $\mathrm{AN}$. Alergia cutânea à apresentação liofilizada da eritropoietina. J. Bras Nefrol. 2004;27:37-39.

28. Da cruz EAS, Lugon JR. Revisão/Atualização em diálise: prevenção e tratamento da osteodistrofia renal. J Bras Nefrol. 1996;18:295-301.

29. Bourquelot P, Raynaud F, Stolba J, Marie L, Meria P, Cussenot O. Traitement chirurgical des complications des abords vasculaires artérioveineux pou hémodialyse chronique. Encycl Méd Chir. 1998;43-029.S 0p.

30. Nascimento MM, Riela MC. Avaliação de acesso vascular em hemodiálise: um estudo multicêntrico. J Bras Nefrol. 1999;21:22-29.

31. Maurice PDL. Acquired perforating dermatosis in renal patients. Nephrol Dial Transplant. 1997;12:2774-5.

32. Lynde $\mathrm{CB}$, Pratt MD. Acquired perforating dermatosis: association with diabetes and renal failure. CMAJ. 2009;181:615.

33. Daudén E, Oñate MJ. Calciphylaxis. Dermatol Clin. 2008;26:557-68.

34. Rogers NM, Coates PT. Calcific uraemic arteriolopathy: an update. Curr Opin Nephrol Hypertens. 2008;17:629-34.

35. Wilmer WA, Magro CM. Calciphylaxis: emerging concepts in prevention, diagnosis and treatment. Semin Dial. 2002;15:172-86.

36. Tercedor J, López Hernández B, Ródenas JM. Bullous dermatosis of end-stage renal disease and aluminium. Nephrol Dial Transplant. 1997;12:1083

37. Day RS, Eales L. Porphyrins in chronic renal failure. Nephron. 1980;26:90-5

38. McKane W, Green CA, Farrington K. Porphyria cutanea tarda precipitated by intravenous iron in a haemodialysis patient. Nephrol Dial Transplant. 2001;16:1936-8.

39. Vieira FMJ, Martins JEC. Porfiria cutanea tardia. An Bras Dermatol. 2006;81:573-84.

40. Sampaio SAP, Rivitti EA. Dermatologia. 3 ed. São Paulo: Artes Médicas; 2008. p. 699-700.

41. Green JJ, Manders SM. Pseudoporphyria. J Am Acad Dermatol. 2001;44:100-8.

42. Ting WW, Stone MS, Madison KC, Kurtz K. Nephrogenic fibrosing dermopathy with systemic involvement. Arch Dermatol. 2003:139:903-6.

43. Nainani N, Panesar M. Nephrogenic systemic fibrosis. Am J Nephrol. 2009;29:1-9.

44. Cowper SE, Su LD, Bhawan J, Robin HS, LeBoit PE. Nephrogenic fibrosing dermopathy. Am J Dermatopathol. 2001;23:383-93.

45. Weigle JP, Broome DR. Nephrogenic systemic fibrosis: chronic imaging findings and review of the medical literature. Skeletal Radiol. 2008;37:457-64.

46. Elias Jr J, Santos AC, Koenigkam-Santos M, Nogueira-Barbosa MH, Muglia VF Complicações do uso intravenoso de agentes de contraste à base de gadolínio para ressonância magnética. Radiol Bras. 2008;41:263-7.

\footnotetext{
MAILING ADDRESS / ENDEREÇO PARA CORRESPONDÊNCIA:

Omar Lupi

Rua Frei Leandro, 16, Ap. 501 - Lagoa

22470-210 Rio de Janeiro - RJ, Brazil

Fax: (21) 2522-6346

E-mail: omarlupi@globo.com
}

How to cite this article/Como citar este artigo: Lupi O, Rezende L, Zangrando M, Sessim M, Silveira CB, Sepulcri MAS, Duarte DJ, Cardim P, Fernandes MM, da Rosa Santos O. Cutaneous manifestations in end-stage renal disease. An Bras Dermatol. 2011;86(2):319-26. 